\title{
Tales of the Survivors: The Bumiputera Entrepreneurs' Experience
}

\author{
Suraiya Ishak \\ School of Social, Development and Environment, Faculty of Social Sciences and Humanities \\ Universiti Kebangsaan Malaysia, 43600 Selangor, Malaysia \\ Tel: 60-3-8921-5244Ｅ-mail: suraiya@ukm.my
}

Ahmad Raflis Che Omar

School of Management, Faculty of Economics and Management

Universiti Kebangsaan Malaysia, 43600 Selangor, Malaysia

E-mail: raflis@ukm.my

Azhar Ahmad

School of Management, Faculty of Economics and Management

Universiti Kebangsaan Malaysia, 43600 Selangor, Malaysia

E-mail: azah@ukm.my

Received: September 18, 2011

Accepted: October 24, $2011 \quad$ Published: March 1, 2012

doi:10.5539/ass.v8n3p25

URL: http://dx.doi.org/10.5539/ass.v8n3p25

\begin{abstract}
Survival in the highly precarious business environment demands credible and resilient entrepreneurs. The issue evolves from merely "how to get started" towards "how to reach the highest potential throughout the entire business life cycle". It is expected that entrepreneurs encounter several turbulences throughout their business cycles before stabilizing within the growth range. It is also posited that each cycle reflects different kind of challenges and barriers, thus leading to different moves and strategies. The ability to react accurately to those challenges will provide different business outcomes. This article aims to describe and reveal the experience of Malay (also known as Bumiputera or son of the soil) entrepreneurs pertaining to their business endeavours. This study adopted a case-study technique with four Malay entrepreneurs through in-depth interviews. This study concluded that all respondents encountered a period of turbulence before making a move to another stage of business cycle. To initiate the turning point, these entrepreneurs introduced some changes either in their products or job processes. In addition, the respondents noted that entrepreneurs without some working or industrial knowledge took relatively longer periods to reach their turning point. Experience entrepreneurs would reach the turning point earlier due to the benefits gained from their past business network as well as the enrichment of tactical and managerial tacit skills that they had acquired.
\end{abstract}

Keywords: Entrepreneurs experience, Bumiputera entrepreneurs, Business challenges

\section{Introduction}

Survival in an intense business competition demands extra-ordinary effort and credibility. As a result, entrepreneurs will move along a continuum of growth cycle with specific challenges and turbulences. This article aims to describe the challenges encountered by Malay entrepreneurs throughout the qualitative investigation. It is shown that qualitative approach is able to comprehend better the patterns of struggles encountered by the business survivors rather than the survey method (Deakins et al., 2002).

The entrepreneurs' struggles are expected to be similar with the evolution of organic creatures as described by the Darwinism theory. According to the theory, various species of living things evolved due to the actions of environment which favoured the survival of some creatures and the destruction of others. As a result, the fittest species will survive in the environment and this phenomenon is also similar to the description of business growth 
and survival. Hence, this paper is unique at describing the entrepreneurs' struggle of existence based on Darwin's Survival of the Fittest theory.

\subsection{Malays Entrepreneurs}

The unique characteristic of Malaysian society is derived from the element of pluralism comprises of various races, ethnics, culture, language and religions (Hwang, 2003). The three main races consist of Malay, Chinese and Indian. In addition, there are also other indigenous groups of people in Peninsular Malaysia, Sabah and Sarawak. The most basic population division of Malaysian society is between Bumiputera (son of the soil) and non-Bumiputera people. The Malay group constitutes the principal Bumiputera group together with other indigenous people. "Bumiputera" refers to those whose cultural affinities indigenous to the region and to one another; whilst those whose cultural affinities lie outside are classified as the non-Bumiputera (Hwang, 2003). The "Bumiputera" term which was introduced in 1971 attempt to exclusively define the indigenous group of Malaysian community with consideration of its' long history since the Malacca era (Shamsul, 2001). Since the discussion of "Bumiputera" identity and definition is particularly complex (Shamsul 2001: 73-78), thus it should be left to competent scholars of the relevant area. Nevertheless, a practical scope of definition of Bumiputera and non-Bumiputera for this study is sufficient. Vejai (2007) highlighted that Bumiputera comprises Malays as well as Sabah and Sarawak native groups, whereas the non-Bumiputera refers to the Chinese, Indians and other non-indigenous people.

The colonial system had segregated Malaysian according to their racial status in many aspects (Hwang, 2003; Thillainathan, 1976). The segregation had assimilated within the society's structure which eventually led to the identification of ethnics according to regions and their economic functions. For instance, the Chinese are relatively concentrated in urban areas in developed states such as Penang, Perak and Selangor. They are known as successful traders and business people. Meanwhile, the Malays are concentrated in less developed states such as Terengganu, Kelantan and Pahang and they are associated with the small scale agricultural and rural based sectors and impoverishment (Hwang, 2003).

The country's development policies such as the New Economic Policy (NEP) (1972-1990), New Development Policy (NDP) (1991-2000), National Vision (2001-2010) and currently the New Economic Model, have largely concentrated at correcting the society's imbalance. The policies rectify the imbalances through various programmes and some affirmative action aiming to spread more opportunities for the vulnerable groups. One of the agenda is to build resilient Bumiputera entrepreneurs in order to correct the income and wealth imbalances. Currently, the number of Bumiputera entrepreneurs in the country has been fast increasing and a majority of them have ventured into small to medium business enterprises.

To promote resilient Bumiputera businesses, the government gives various aids to deter self-extinction among the Bumiputera due to their incapability to compete with other stronger and well-established competitors (Mun, 1987; Ragayah \& Zulkifli 1998). Therefore, government plans to develop credible Bumiputera Commercial and Industrial Community (BCIC) such as introducing the konsep payung (umbrella concept) which aims to assist Bumiputera to market their products through companies that have registered with the programmes (Faridah, 2001). Other aids include easing the financial needs of Bumiputera entrepreneurs as well as enhancing their skills and technology (Faridah 2001: 88-89). All these may help to ensure the survival of Bumiputera entrepreneurs within the intense competition especially from the matured players of the industry. With such aids, Bumiputera entrepreneurs are given opportunities as well as platforms to progress and deters the self-extinction phenomenon (Ragayah \& Zulkifli, 1998; Triantafillou, 2005).

\section{Literature Review}

\subsection{Survival of the Fittest}

Darwin applied a biological view to deliberate social issues as well as the laissez-faire economics concept (Weikart 1998; Velasquez, 2002). Human struggle of existence is expected to hold similarities to the survival of other organic creatures under the natural laws assumptions. Darwin described the struggle for existence as (in Weikart 1998: 20);

"Hence, as more individuals are produced than can possibly survive, there must in every case be a struggle for existence, either one individual with another of the same species, or with the individuals of distinct species, or with the physical conditions of life" 
Entrepreneurs possess unique characteristic which transcends the boundary of merely owning a business venture. Gray (2002: 62) defined entrepreneurs "....as individuals who manage a business with intention of expanding the business and with leadership and managerial capacity for achieving their goals, in the face of strong competition from other firms, large and small". According to Runyan et al. (2008), business owners are individuals who established and managed business for the purpose of personal goals and agendas as well as to generate family income. Entrepreneurs and small business owners are distinguishable concepts in terms of their goal orientation as the latter emphasize on the short-term personal goals. Thus, entrepreneurial orientation is able to influence superior performance among the small medium enterprises (Amran, et al., 2010; Runyan, et al., 2008).

\subsection{Challenges Faced by Entrepreneurs}

There are many obstacles than can potentially obstruct the entrepreneurs' business progress such as the scarce of resources and capabilities as well as institutional deficiencies (Gray, 2002; Welter and Smallbone, 2011). Amran et al. (2010) suggested that today's enterprises need to embrace strategic entrepreneurship in order to survive within the new competitive landscape. However, as far as small business is concerned, not all small business owners are qualified entrepreneurs (Runyan et al., 2008; Thurik and Wennekers, 2004). Gray (2002) proposed that successful entrepreneurs must apply high level of managerial competence in the five stages of knowledge necessities as shown in Figure 1.

$<$ Insert Figure 1 here $>$

Gray (2002) concluded that the problems of entrepreneurs are likely to be strong on the left side of the diagram which refers to the input and transformation stages. On the input side, studies on small and medium firms have emphasized on the financial capital problem (Gregory et al., 2005; Owualah, 1999; Ragayah \& Zulkifli, 1998). According to Gregory et al. (2005), firm size, age and availability of information would retard the attractiveness of financing option for small firms. As a result, small businesses tend to face difficulties to obtain financial aid from financial institutions or agencies thus, they need more creativity in searching for alternative solutions. Owualah (1999) had examined the effect of long standing relationship between small-medium enterprises (SMEs) and banks. He reported that the relationship is no longer guaranteed for SMEs to have access to bank credits especially in a country of deteriorating financial condition. The lack of capital may also lead to a bundle of problems for small enterprises such as unattractive size and site of enterprise, low quality labour, small market coverage, sub-standard raw materials and machinery, and low quality productions (Sharma, 1979). Furthermore, financial inadequacy at the initial stages of the enterprises would retard its progress, create severe financial crisis and transform the enterprise into a sick unit.

According to Howorth and Wilson (1999), most small firms encountered late payment problems. In addition, firms which suffered from the late payment problem were typically undercapitalized, had poor credit management practices and unable to take action on debtors' late payment. The late payment problems were also originated from the marketing weaknesses and many Malaysian entrepreneurs were pressured to extend credit facilities to their customers as part of their marketing strategy (Sharma, 1979). However, such strategy only works for short term as the entrepreneurs would encounter shortage of working capital and distort their future operations.

Among the small firms, there is diversity in financial management practices (Deakins, et al., 2002). Small firms' financial management capability evolves a dynamic process of learning which encompasses the influence of both the external and internal environments. Their findings conclude that learning process follows a dynamic evolution that is unique for each organization. Hence, no standard solution readily suits to all small firms due to their heterogenic internal and external influences. In order to progress some amount of tacit experience is fundamentally required in all aspects of business operations and managerial capabilities. Unfortunately, in many circumstances small firms often had no time to learn effectively from their experience and the firms would then continue with their normal routine (Gray, 2002). Consequently, these SME entrepreneurs would lag behind in terms of making innovations and improvement. Another challenge that may impose significant challenge on entrepreneurial behaviours and business achievement is the institutional pressures (Welter \& Smallbone, 2011). This factor is apparently challenging within the emerging and transition economies such as Malaysia.

All the challenges represent obstacles that potentially distort business achievements among the Bumiputera (Ragayah \& Zulkifli, 1998). Those challenges may surface in any of the five (5) stages thus, deserving strong ability as well as knowledge to manage the challenges effectively. Knowledge and skills are the required elements that ensure survival in the market. Failing to manage the challenges may succumb towards business failures due to inability to compete with stronger market players. This phenomenon is described analogically to the nature of intense competition of the animal world as described by Darwinism (Weikart, 1998). Velasquez 
(2002) had similarly argued that aggressive business competition only allows the "fittest" entrepreneurs to remain in the market structure.

\section{Methodology}

This study employs case study to understand the challenges encountered by the Malay entrepreneurs. This approach is parallel to a study by Deakins et al. (2002) who employed case study to understand the evolutionary process of financial management practices for the small firms. Case study is able to comprehend detailed insights on the evolution aspect of the studied subject compared to the relatively static survey-based approach.

This study involved four Malays entrepreneurs from different sectors. The selection of respondents was made through a non-probability purposive sampling technique. The data were gathered through in-depth interviews conducted approximately about 2 to 3 hours per individual. The data were then analyzed descriptively. The interview sessions were guided by five structured questions;

Background of business and owners?

Problem(s)/challenge(s) encountered throughout each business cycle?

Strategy to react against the respective problems?

Reasons of failure (where applicable)?

Describe current achievement?

\section{Analysis and Discussion}

From the analysis, all entrepreneurs have a college qualification. Mr. I, H and R had graduated with a degree in accounting and Mr. W had a diploma in tourism. Mr. I, H and W started their business immediately after their tertiary education while, Mr. R started his business after 5 years working in a trading company. Mr. I, $\mathrm{H}$ and W ventured into business at their early twenties and Mr. R started in his late twenties. Table 1 shows the background of the business and its owners.

$<$ Insert Table 1 here $>$

Table 2 summarizes the transcribed information on the success and under-performance factors as identified by each respondent. From the cases, the survivors have encountered turbulence phase in their early stage of business involvement, especially at least for the early three years.

$<$ Insert Table 2 here $>$

Figure 2 illustrates the trend of entrepreneurs' evolution. In summary, the entrepreneurs would encounter strong turbulence in the early years of their establishments and the challenges then subsided as the company progressed.

$<$ Insert Figure 2 here $>$

Table 3 compares the results of the survivors before and after their turning point. For example, Mr. I's early failure was due to no guidance from mentor to provide technical guidance and advices, inability to make innovations, and small limited market. He also mentioned that the trap of bankers risk adverse syndrome had inhibited his creativity and innovation. Meanwhile, Mr. H's weak performance was resulted from skills incompetency such as lack of technical knowledge and marketing skills. In addition, Mr. H faced problems of bad debts as well as being trapped in the financer's risk adverse syndrome. As noted by the third respondent, Mr. $\mathrm{R}$ claimed that his slow performance was due to the marketing and regulations problems. Finally, Mr. W who had yet reached his turning point, related his business challenge to the tight regulations and insufficient resources to finance his transportation project.

$<$ Insert Table 3 here $>$

The pace of reaching the turning point also varies among the respondents. Those who ventured in business without working experience took longer periods to stabilize such as in the case of Mr. I and Mr. H. They started business immediately after graduation and their business took about 13 years to reach the turning point of the growth stage. However, Mr. W has yet to reach the turning point since his business tenure is currently about 10 years (2001- 2011). For Mr. R, his turning point developed relatively faster (about three years) as compared to Mr. I and Mr. H.

The obvious difference between Mr. W and both Mr. I and Mr. H was that Mr. W did not make any changes in his business operation, either in his product line (business) or process technology. Both Mr. I and Mr. H had implemented changes in their operations in order to leap the turning point of another stage in the business cycle. In order to initiate a turning point, it is necessary for the entrepreneurs to implement some changes in their 
business operations rather than adopting a defensive type of action. As far as changes is concern, Mr. I had introduced a new product whereas Mr. H implemented new technology in doing the job.

Based on the respondents' experience, some rules of thumb pertaining to the improvement and innovative actions of small firms can be concluded. First, the improvement and changes of their operation need not be big. For example, Mr. $\mathrm{H}$ had changed from off-set printing to digital printing. Second, the improvement must facilitate people's needs. For instance, Mr. I's simple but focus ideas on bulk texting system had enormous impact since the system facilitates other small business operators to communicate with their customers. Third, the entrepreneurs must possess basic technical knowledge of their business industry in order to initiate some improvement. In this case, Mr. I managed to develop a new product through his technical qualification since he possessed a master degree in IT. Similarly, Mr. H developed his technical knowledge through his 13 years experience in printing industry. Likewise, Mr. R gained his technical knowledge through his working experience and Mr. W from his family's transportation business.

In order to implement changes and improvement, entrepreneurs must be confident and not to be over dependent on other opinions especially when it comes from the banking or other similar agencies. These agencies tend to impose their conservative values which could hinder innovativeness among the entrepreneurs. As a result, innovative but risky ideas would be rejected and the entrepreneurs are trapped since they are unable to venture into a more prospective and profitable business. For example, Mr. I had submitted a loan application parallel to his new ideas which the bank had rejected. As a result, he was frustrated and his business performance had been locked at the stagnant level between 2002 and 2009. However, after meeting a business mentor he gained a new spirit and started working out his idea aggressively using his own fund. After going through a passage of hardship, he successfully developed a product which has shown positive results. On the other hand, if the entrepreneurs rely too much from outsiders' funds, it would limit their ability to choose actions beyond others expectations. Hence, entrepreneurs must possess sufficient internal financial resources especially during their early thrive in order to reach the turning point of the growing stages.

Most of the respondents also showed some degree of frustration in terms of getting financial aids from outside sources such as banks and other financial agencies;

Mr. I: "Never rely on bankers. They trapped you with their myths. They rarely support your innovative and risky ideas... and they will ask you to follow their old fashion, conservative and typical course of business. But that will kill your business growth. You cannot move further. Sometimes they feed you with wrong information and develop negative traits inside you...until you become a person with inferiority complex and lack of self-confident...."

Mr. R: "Banks and financing agencies only like you when you are already rich. When you have reached the peak level, then only they started offering you all kinds of facilities. Before that, when you are climbing up the rocking rocks...they just don't' bother (with) your applications, even they demand for all sorts of requirements, for example land-collateral. If we have that much resources, we won't begging for the loans or grants... also they offer pieces of advice which I wonder did they ever experience the situation (in which) we are grappling with before they throw the perfect advices? After all, I believe that they (bank and the equivalent institutions) are meant only for the rich and the successors... not for the beginners....."

Mr. H: "You know what...I just made an application to government agencies for some loan. Last week they came to visit my office. They ask me for my accounts...Unfortunately I don't have the proper record of accounts throughout my business life. I really know the important of book-keeping and the preparation of accounts... besides, I'm a bachelor of accounting... but, could you imagine..., running this venture on a one man-show. (To) Hiring someone to do the accounts also need some cost.... I'm grappling running this business and resources must be fully optimized for the operations. Back to my loan application, it was rejected...."

Mr. W: “...Let us put the matter this way... they (the banks or other equivalent agencies) may give you... but the amount will be cut-off here and there. It is insufficient to cover your business needs."

From the study, external funding is essential if the entrepreneurs are involved in a high-investment project. As the case of Mr. I, the cost of investment to develop the bulk texting system is relatively low. However, Mr. H needed to purchase expensive printing machines and equipments, while Mr. W had to purchase a brand new bus. Therefore, the ability to innovate would be restricted if the industry demands high investment.

An entrepreneur also requires a good and enthusiast mentor. For example, Mr. I managed to regain his entrepreneur spirit after sharing his problems with Mr. A. Mr. A is a successful entrepreneur who had guided Mr. 
I to overcome his business hurdles. Besides, Mr. A was also the one that shared his client with Mr. I by introducing the texting system to his business clients.

In short, survival of the fittest involved tough and long thrives. Thus, these Malay entrepreneurs' struggles of existence were very similar to the existence of other organisms. A successful thrive involves making accurate adjustments and reactions to the obstacles surrounding the business environment.

\subsection{Pragmatic Implications}

From the analysis, several implications could be highlighted. First, entrepreneurs should begin their business venture at a younger age. This is because the development of business skills and maturity would require some time, for example after 13 years of involvement. Furthermore, technical and marketing knowledge are important in order to progress. The authority concern should consider some mechanisms to allow more entrepreneurial initiatives within the community especially in terms of providing loans to accommodate the business tight financial needs.

Second, banks and other related agencies must equally facilitate SMEs during their infant years due to the hardship they encountered throughout these early periods. The preference for established and secured venture would eventually result in the deteriorating of innovativeness and entrepreneur orientation among small business owners. As a result, such institutional condition will limit business ventures to relatively low risk industries and low growth capacity.

Third, financiers should evaluate the SMEs based on their unique characteristic and not to have a standardized evaluation or perception towards different SMEs. This is due to the different situation, needs and problems faced by the entrepreneurs during their struggle to survive. To ensure stability, some kind of affirmative actions are required to balance the inequality of income and wealth distribution among community members. For the affirmative programme to be successful, it must include some elements that are able to nurture strong competitive culture and attitudes among the entrepreneurs.

Fourth, a mentoring programme encompasses strategic coaching by successful entrepreneurs would be beneficial in order to share real business experience and offer mutual benefits (such as sharing of the market-niche, marketing strategies and networking) among the small entrepreneurs. From the cases, it was concluded that business skills were inclined towards the tacit-practical type of knowledge (skills) which rarely transferred formally from one skill to another. Therefore, this study justifies the needs for an experiential learning approach for business and entrepreneurship education rather than the classroom-based approach.

\subsection{Future Research Directions}

Future research could be expanded by making a comparison between Bumiputera versus the non-Bumiputera survival of the fittest. This is important as the struggles might be different since the non-Bumiputera received less aids form the government and thus they may adopt different survival approach.

Future research should validate the relationship between longevity of business (whether 13 years is the accepted cutting point) and the ability of entrepreneurs to reach the turning point. This ability could also be referred to the introduction of new ideas (innovation) which catalysts the process of business transformation from the passive towards the early stage of relatively accelerated growth momentum.

\section{Conclusions}

In a nutshell, most entrepreneurs would face a period of turbulence before reaching their business-success turning point. The turning point is potentially obtained after a significant change or improvement in the business product or process. Based on the respondents' experience, several necessary elements for a successful business survivor are highlighted:

If possible start business venture at younger age since most of the Malay entrepreneurs started their business in their early 20's. This is essential as the business would take some time to evolve to its maturity and success. As proven by the selected cases, the respondents took more than 10 years to prosper and unless they have specific experience then the turbulence periods could be shorter.

Introduce change or innovation either in the product or the process. As shown by the cases, the turning points appeared as the respondents made accurate choice of changes in their business operation. However, the ability to make necessary changes also required tacit knowledge which was developed throughout the passage of time and experience. 
Believe in owns ideas and never trapped in other's opinion. The bankers will always resort for conservative idea as they try to minimize risks but the action will negatively affect the business. Hence, it is helpful if the entrepreneurs have their own resources rather than relying on bank loans.

Establish networking and look for credible as well as trust-worthy mentor to share problems or seek opinions. In addition, in depth technical knowledge related to the business product is essentially important to lead innovative venture.

\section{References}

Amran Awang, Zainal Ariffin Ahmad, Abdul Rashid Said Asghar and Khairul Anwar Subari. (2010). Entrepreneurial orientation among Bumiputera small and medium agro-based enterprises (BSMAEs) in West Malaysia: policy implication in Malaysia. International Journal of Business and Management, 5(5), 130-143.

Deakins, David, A. Morrison and L. Galloway. (2002). Evolution, financial management and learning in the small firm. Journal of Small Business and Enterprise Development, 9(1), 7-16. http://dx.doi.org/10.1108/14626000210419446

Faridah Shahadan. (2001). Bumiputera commercial and industrial community in the food-processing industry: an analysis of institutional support. Humanomics, 17(1/2): 86-98. http://dx.doi.org/10.1108/eb018862

Gray, Colin. (2002). Entrepreneurship, resistance to change and growth in small firms. Journal of Small Business and Enterprise Development, 9(1), 61-72. http://dx.doi.org/10.1108/14626000210419491

Gregory, Brian T., M.W Rutherford, S. Oswald and L. Gardiner. (2005). An empirical investigation of the growth cycle theory of small firm financing. Journal of Small Business Management, 43(4), 382-392. http://dx.doi.org/10.1111/j.1540-627X.2005.00143.x

Howorth, Carole and N. Wilson. (1999). Late payment and the small firm: an examination of case studies. Journal of Small Business and Enterprise Development, 5(4), 307-315. http://dx.doi.org/10.1108/EUM0000000006795

Hwang, In-Won. (2003). Personalized Politics. The Malaysian State under Mahathir. Pasir Panjang Singapore: Institute of Southeast Asian Studies.

Mun, K.S. (1987). Documenting papers on Bumiputera participation in the Malaysia economy. Library Review, 110-121. http://dx.doi.org/10.1108/eb012838

Owualah, Sunday I. (1999). SMEs, borrowing constraints and banking relationships in Japan. Japan and the World Economy, 14, 87-100. http://dx.doi.org/10.1016/S0922-1425(99)00034-1

Ragayah Haji Mat Zin and Zulkifli Senteri. (1997). Exploring probable factors determining the success of Bumiputera entrepreneurs. Humanomics, 14(1): 31-58.

Runyan, Rodney, C. Droge and J. Swinney. (2008). Entrepreneurial orientation versus small business orientation: what are their relationship to firm performance? Journal of Small Business Management, 46(4), 567-588. http://dx.doi.org/10.1111/j.1540-627X.2008.00257.x

Shamsul, A.B. (2001). 'Malay' and 'Malayness' in Malaysia reconsidered: a critical review. Communal/Plural, 9(1), 69-80. http://dx.doi.org/10.1080/13207870125429

Sharma, S.V.S. (1979). Small Entrepreneurial Development. New Delhi: Light \& Life Publishers, 233-242.

Thillainathan, R. (1976). Part 1: Malaysia. In The Role of Public Enterprises in National Development in Southeast Asia: Problems and Prospects. Ed. Nguyen Truong. Heng Mui Keng Terrace, Singapore: Regional Institute of Higher and Development, 1-16.

Thurik, Roy and Wennekers, S. (2004). Entrepreneruship, small business and economic growth. Journal of Small Business and Enterprise Development, 11(1): 140-149. http://dx.doi.org/10.1108/14626000410519173

Triantafillou, P. (2005). "Politics have shown that the Malays can change": corporate anthropology and the governing of entrepreneurial subjectivities in Malaysia. Journal for Cultural Research, 9(2): 207-224. http://dx.doi.org/10.1080/14797580500063598

Vejai, Balasubramaniam. (2007). A divided nation: Malay political dominance, Bumiputera Material advancement and national identity in Malaysia. National Identities, 9(1), 35-48. http://dx.doi.org/10.1080/14608940601145679

Velasquez, Manuel, G. (2002). Business Ethics. Concepts and Cases. Upper Saddle River, New Jersey: Prentice Hall. 
Weikart, Richard. (1998). Laissez-Faire Social Darwinism and individualist competition in Darwin and Huxley. European Legacy, 3(1), 17-30. http://dx.doi.org/10.1080/10848779808579861

Welter, Friederike and Smallbone, D. (2011). Institutional perspectives on entrepreneurial behavior in challenging environments. Journal of Small Business Management, 49(1): 107-125. http://dx.doi.org/10.1111/j.1540-627X.2010.00317.x

[Online] Available: http://www.epu.gov.my/chapter1?p_p_id=56_INSTANCE_tQQe\&p_plifecycle=0\&p_pp... (May 11, 2011)

Table 1. Background of Respondents

\begin{tabular}{|c|c|c|c|}
\hline No. & Respondent background & Nature of Business & Year of establishment \\
\hline \multirow[t]{2}{*}{1.} & \multirow{2}{*}{$\begin{array}{l}\text { MR. I: } \\
\text { Bachelor of Accounting \& } \\
\text { Master degree in IT. }\end{array}$} & Photocopy & 1997 \\
\hline & & $\begin{array}{l}\text { IT based and telecommunication service } \\
\text { provider }\end{array}$ & 2010 \\
\hline 2. & $\begin{array}{l}\text { MR. H: } \\
\text { Bachelor of Accounting. }\end{array}$ & Printing & 1999 \\
\hline 3. & $\begin{array}{l}\text { MR. R: } \\
\text { Bachelor of Accounting }\end{array}$ & Trading of machineries \& equipments. & 2003 \\
\hline 4. & $\begin{array}{l}\text { Mr. W: } \\
\text { Diploma in Tourism. }\end{array}$ & Transportation (buses) & 2001 \\
\hline
\end{tabular}

Table 2. Success and Failure Factors

\begin{tabular}{|c|c|c|c|c|}
\hline Respondents & $\begin{array}{l}\text { Under perform } \\
\text { period }\end{array}$ & Failure factors & $\begin{array}{l}\text { Lap time before } \\
\text { turning point }\end{array}$ & Success factors \\
\hline Mr. I & $1997-2009$ & $\begin{array}{l}\text { No mentor. } \\
\text { No innovations. } \\
\text { Small (limited) market } \\
\text { Trap into bankers risk adverse } \\
\text { syndrome. }\end{array}$ & $\begin{array}{l}2010 \text { - lap time: } \\
13 \text { years }\end{array}$ & $\begin{array}{l}\text { Innovative and niche } \\
\text { product. } \\
\text { Technical knowledge } \\
\text { Right mentor. } \\
\text { Right actions } \\
\text { Effective marketing } \\
\text { Willing to change }\end{array}$ \\
\hline Mr. H & $1999-2009$ & $\begin{array}{l}\text { Lack of technical knowledge } \\
\text { Ineffective marketing and lack of } \\
\text { marketing skills/capabilities. } \\
\text { Credit collection and bad debts } \\
\text { problems. } \\
\text { Trap into financer agency risk } \\
\text { adverse syndrome }\end{array}$ & $\begin{array}{l}2010 \text { - lap time: } \\
13 \text { years }\end{array}$ & $\begin{array}{l}\text { Move to digital printing } \\
\text { after purchased the } \\
\text { machine. } \\
\text { Improved technical } \\
\text { knowledge and skills. }\end{array}$ \\
\hline Mr. R & 2003 & $\begin{array}{l}\text { Unable to market product } \\
\text { Rules and regulations hinder } \\
\text { capacity to beat competitors. }\end{array}$ & $\begin{array}{l}2006 \text { - lap time: } \\
3 \text { years }\end{array}$ & $\begin{array}{l}\text { Improved networking. } \\
\text { Personal marketing. }\end{array}$ \\
\hline Mr. W & 2001 & $\begin{array}{l}\text { Tight control of transportation } \\
\text { industry. } \\
\text { Insufficient financing \& inflexible } \\
\text { loan requirements. }\end{array}$ & Not applicable & \\
\hline
\end{tabular}


Table 3. Achievement of Survivors Before and After Turning Point

\begin{tabular}{|l|c|c|c|c|c|c|}
\hline $\begin{array}{c}\text { Dimensions of } \\
\text { Achievement }\end{array}$ & \multicolumn{2}{|c|}{ Respondent I } & \multicolumn{2}{c|}{ Respondent H } & \multicolumn{2}{c|}{ Respondent R } \\
\hline & Before & After & Before & After & Before & After \\
\hline Number of employees & 2 & 6 & 2 & 4 & 3 & 8 \\
\hline $\begin{array}{l}\text { Sales turn over } \\
\text { US\$ (approximately) }\end{array}$ & 252,000 & 490,000 & 105,000 & 700,000 & $2,100,000$ & $7,000,000$ \\
\hline
\end{tabular}

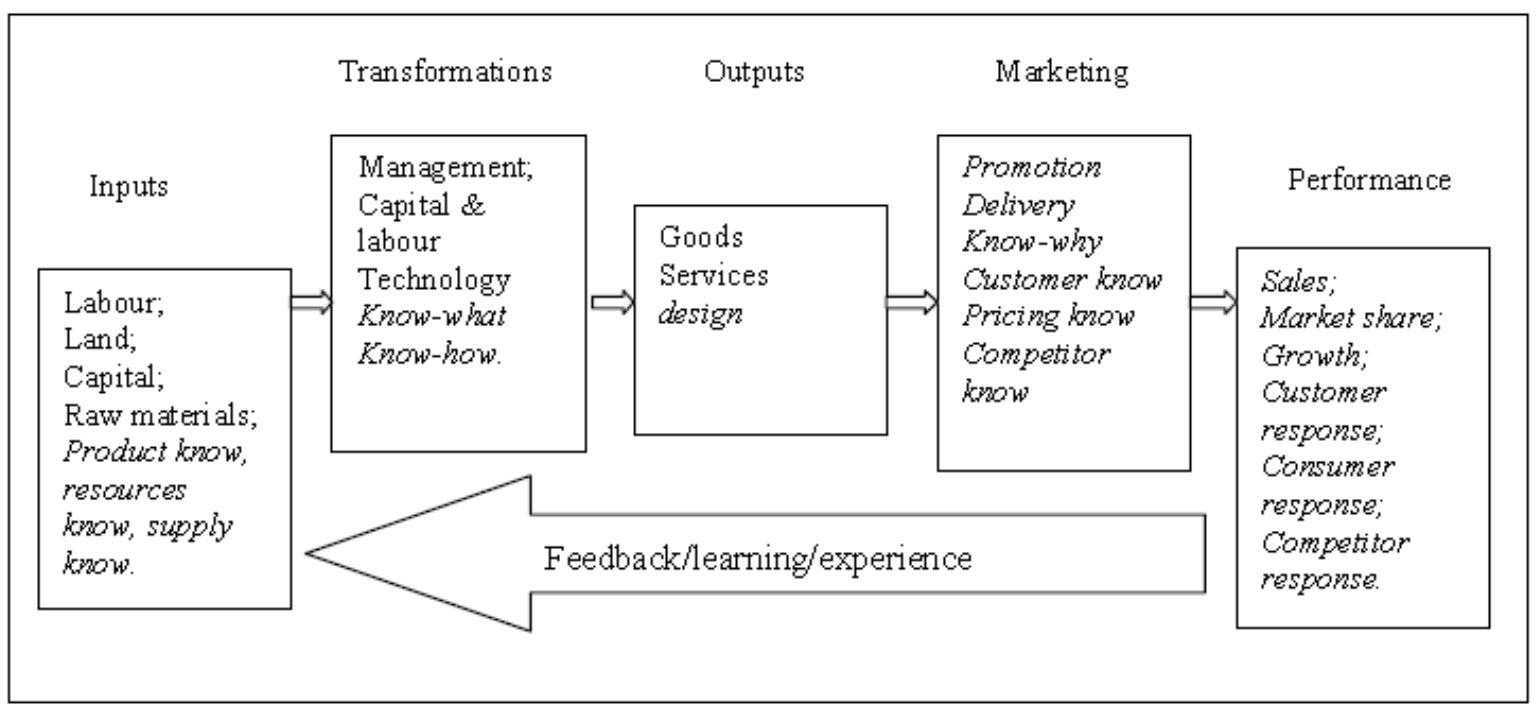

Figure 1. Value Chain of Knowledge Needs in the Small Firm

Source: From Gray, 2002: 63

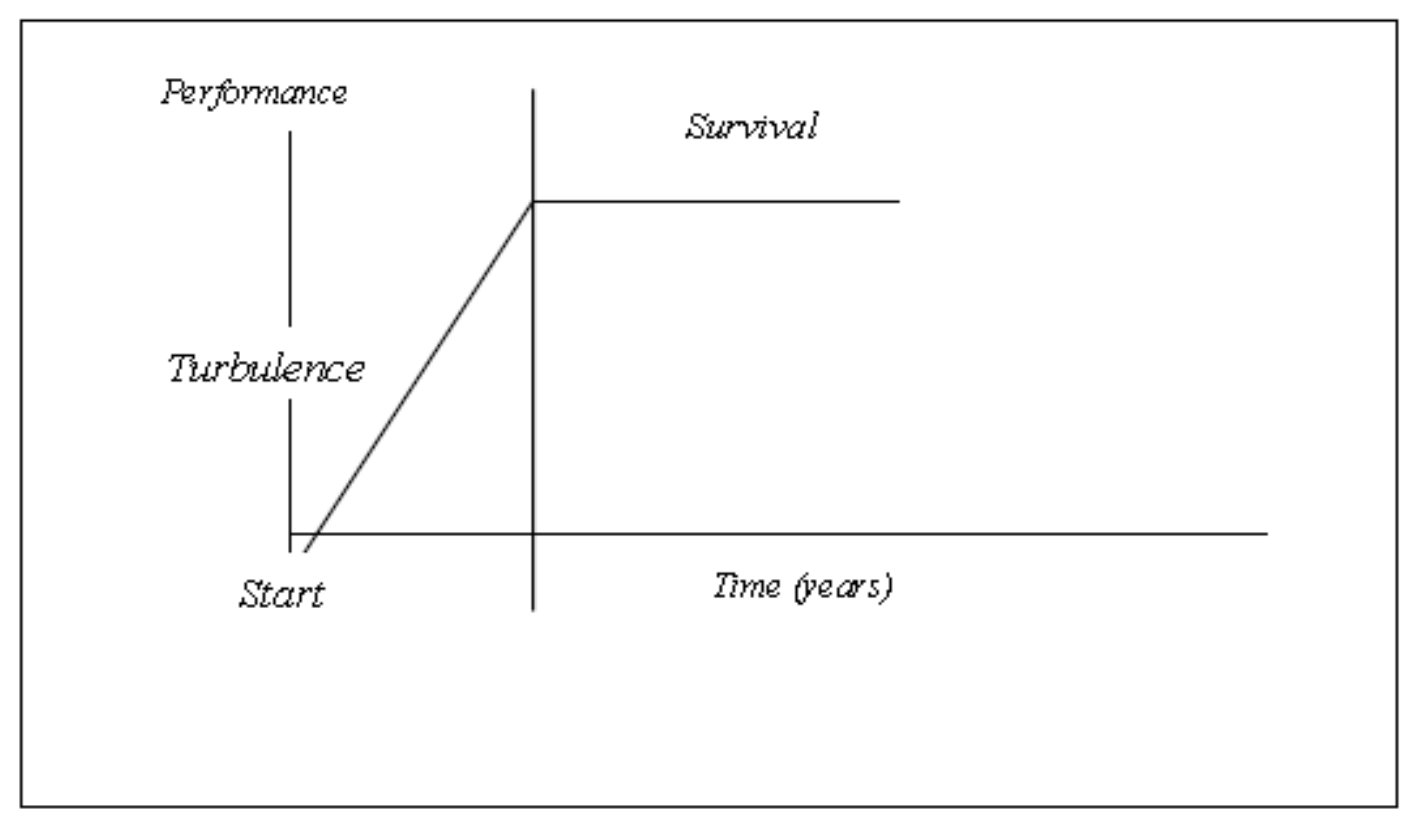

Figure 2. Trend in Entrepreneur Survival Progress 